\section{Policy Research Working Paper \\ Shaping Future GATS Rules for Trade in Services}

Aaditya Mattoo
WPS 2596

2596
The General Agreement on

Trade in Services (GATS) has created a more secure environment for trade in services, but it has not generated the negotiating momentum to reduce protection or the rules to ensure that protection takes a desirable form. In dealing with the trade-impeding impact of domestic regulations, it has achieved even less.

The World Bank

Development Research Group

Trade

April 2001 


\section{Summary findings}

The new round of negotiations has begun with a mechanical sense of "since we said we would, therefore we must," says Mattoo. To make the General Agreement on Trade in Services (GATS) more effective at liberalization, Mattoo suggests improving the agreement's rules, countries' specific commitments, and the negotiating methodology:

- Wasteful regulations and entry restrictions pervade trade in services. Unlike the GATT, the GATS has created no hierarchy of instruments of protection. It may be possible to create a legal presumption in favor of instruments (such as fiscal measures) that provide protection more efficiently.

- Many countries have taken advantage of the GATS to create a more secure trading environment by making legally binding commitments to market access. The credibility of reform would increase with wider commitments to maintain current levels of openness or to increase access in the future.

- Multilateral rules on domestic regulations can help promote and consolidate domestic regulatory reform, even when the rules are designed primarily to prevent the erosion of market access for foreign providers. The pro-competitive principles developed for basic communications could be extended to other network- based services sectors, such as transport (terminals and infrastructure) and energy services (distribution networks). The "necessity test" instituted for accounting services could be applied to instruments in other sectors (so that doctors judged competent in one jurisdiction wouldn't have to be retrained for another, for example).

- Anticompetitive practices that fall outside the jurisdiction of national competition law may be important in such sectors as maritime, air transport, and communications services. Strengthened multilateral rules are needed to reassure small countries with weak enforcement capacity that the gains from liberalization will not be appropriated by international cartels.

- Explicit departures from the most-favored-nation rule matter most in such sectors as maritime transport, audiovisual services, and air transport services-which have been excluded from key GATS disciplines. Implicit discrimination can be prevented by developing rules to ensure the nondiscriminatory allocation of quotas and maintaining the desirable openness of the GATS provision on mutual recognition agreements.

- Reciprocity must play a greater role in negotiations, if the GATS is to advance liberalization beyond measures taken independently.

This paper-a product of Trade, Development Research Group-was prepared for a National Bureau of Economic Research conference on Trade in Services, held in Seoul in June 2000, and is part of a larger effort in the group to assess the implications of liberalizing trade in services. The research is supported in part by the U.K. Department for International Development. Copies of this paper are available free from the World Bank, $1818 \mathrm{H}$ Street NW, Washington, DC 20433. Please contact Lili Tabada, room MC3-333, telephone 202-473-6896, fax 202-522-1155, email address ltabada@worldbank.org. Policy Research Working Papers are also posted on the Web at http://econ.worldbank.org. The author may be contacted at amattoo@worldbank.org. April 2001. (36 pages)

The Policy Research Working Paper Series disseminates the findings of work in progress to encourage the exchange of ideas about development issues. An objective of the series is to get the findings out quickly, even if the presentations are less than fully polished. The papers carry the names of the authors and should be cited accordingly. The findings, interpretations, and conclusions expressed in this paper are entirely those of the authors. They do not necessarily represent the view of the World Bank, its Executive Directors, or the countries they represent. 


\title{
SHAPING FUTURE GATS RULES FOR TRADE IN SERVICES
}

\author{
Aaditya Mattoo*
}

"Development Research Group (DECRG), World Bank, 1818 H Street, NW, Washington, DC 20433; Email: amattoo@worldbank.org. This paper was prepared for an NBER Conference on Trade in Services, Seoul, June 2000. It is part of the World Bank's research program on trade in services, supported in part by the United Kingdom Department for International Development. The paper has benefited from the comments of Rolf Adlung, Carsten Fink, Bernard Hoekman, Anne Krueger, Richard Snape, Arvind Subramanian, Chang Tai-Hsieh and other conference participants. 



\section{Non-technical summary}

The GATS can be made a more effective instrument of liberalization without fundamental structural changes. This paper suggests improvements that could be made in the current round of services negotiations in the rules of the Agreement, in the specific commitments made by countries and in the negotiating methodology.

- Wasteful regulations and entry restrictions pervade services trade. Unlike the GATT, the GATS has created no hierarchy of instruments of protection - even though the ranking of instruments in the case of both goods and services is similar. It may not yet be politically feasible to prohibit the use of measures like quotas in services trade, but it may be possible to create a legal presumption in favour of instruments (such as fiscal measures) that provide protection more efficiently.

- Many countries have taken advantage of the GATS to create a more secure trading environment by making legally binding market access commitments. But the coverage of commitments for a large number of countries is limited, and in some cases commitments serve to protect the privileged position of incumbents rather than enhance the contestability of markets. Greater advantage could be taken of the opportunity offered by the GATS to lend credibility to reform programmes by committing to maintain current levels of openness or by precommitting to greater levels of future openness.

- Multilateral rules on domestic regulations can help to promote and consolidate domestic regulatory reform, even when they are designed primarily to prevent the erosion of market access for foreign providers. The original GATS provisions in this difficult area were weak but some progress has been made in the last five years, on which the current negotiations can build. First, the pro-competitive principles developed for basic telecommunications could also be made applicable to other network-based services sectors, such as transport (terminals and infrastructure) and energy services (distribution networks), to ensure that any major supplier of essential facilities provides access to all suppliers, national and foreign, at costbased rates. Secondly, the "necessity test", instituted for accountancy services, could be made applicable also to regulatory instruments in other sectors. This test leaves governments free to deal with economic and social problems provided that any measures taken are not more trade restrictive than necessary to achieve the relevant objective. For instance, in the case of foreign doctors, a requirement to re-train would be judged unnecessary, since a test of competence could determine whether they possess the required skills.

- Anticompetitive practices that fall outside the jurisdiction of national competition law may be important in sectors like maritime, air transport and communication services. Current GATS provisions in this area provide for only information exchange and consultation. Strengthened multilateral rules are needed to reassure small countries with weak enforcement capacity that the gains from liberalization will not be appropriated by international cartels. For instance, two obligations could be created for the maritime sector. The first would require an end to the exemption of collusive agreements from national competition law in the EU, US and other countries. The second would create a right for foreign consumers to challenge anticompetitive practices by shipping lines in the national courts of countries whose citizens own or control these shipping lines. The second obligation is necessary to deal with the possibility of inadequate enforcement by public agencies, and already has a precedent in the WTO rules on intellectual property and government procurement.

- Explicit departures from the MFN rule matter most in sectors like maritime transport, audiovisual services, and air transport services - which have been excluded from key GATS 
disciplines. Progress will not be easy but bundling sectoral negotiations together (e.g. in transport) may help. Implicit discrimination needs to be prevented by developing rules to ensure the non-discriminatory allocation of quotas, and by clarifying and maintaining the desirable openness of the GATS provision covering mutual recognition agreements.

- If the GATS is to advance the process of services liberalization beyond levels undertaken independently, and lead to more balanced outcomes from the developing country point of view, then reciprocity must play a greater role in negotiations. This may be facilitated by devising negotiating formulae that establish credible links across sectors and across modes of delivery. And to overcome a possible hold-back problem, it is necessary to provide credible ex ante assurance of negotiating credit for unilateral liberalization. 


\section{Introduction}

The new round of services negotiations has begun, not with passionate intensity, but a rather mechanical sense of "since we said we would, therefore we must". While the lack of attention from those opposed to freer trade is cause for relief, the lack of conviction in supporters of new negotiations merits concern. The reason for both, however, is the limited impact so far of the General Agreement on Trade in Services (GATS). Creating a framework of rules in this difficult area was certainly an achievement, but the GATS has so far failed to deliver meaningful liberalization. And it has invariably been a step behind technological and regulatory developments in services. The Agreement is generally perceived, not as a scourge of protection, but as a rather stodgy reaper of liberalization accomplished elsewhere.

In highlighting the limitations of the GATS, which is the main purpose of this paper, it is easy to understate what it has accomplished. In recognition of the fact that many services require proximity between consumers and suppliers, the Agreement went beyond the traditional notion of trade (including only cross-border delivery) to encompass supply through the movement of both capital and labour. ${ }^{1}$ The Agreement also created a framework to deal with forms of protection more complex and less visible than tariffs. These include, first, a variety of quantitative restrictions, ranging from cargo sharing in transport services, limits on the number of (foreign) suppliers in telecommunications and banking, to restrictions on the movement of service-providing personnel that affect trade in all services. Then there are numerous forms of discrimination against foreign providers, through taxes and subsidies as well as by allowing less favourable access to essential facilities such as ports, airports or telecommunications networks. And finally, a subtle class of measures that are neither quotas nor explicitly discriminatory but nevertheless have a profound effect on services trade, i.e. domestic regulations such as qualification and licensing requirements.

\footnotetext{
${ }^{1}$ Developed country proponents of the GATS initially envisaged an inclusion only of capital movements, but developing country negotiators successfully pressed for the inclusion of labour movements also.
} 
Gandhi said that it was pointless to dream of systems so perfect that human beings no longer need to be good. It is perhaps equally utopian to wish for international trade rules that can deliver liberalization without the willingness of governments. No doubt liberalization of services is primarily a challenge for domestic policy. Still, multilateral negotiations and agreements can help. In four ways, by helping achieve: deeper liberalization through reciprocity-based market access negotiations; efficient protection and regulation through rules that favour the choice of superior instruments; credibility of policy through legally binding commitments; and a guarantee against discrimination through the MFN principle. How much has the General Agreement on Trade in Services (GATS) already delivered in these respects?

- The GATS has created an adequate framework to deal with explicit protection, but neither the negotiating momentum to reduce such protection nor the rules to ensure that it takes a desirable form.

- In dealing with the trade-impeding impact of domestic regulations, an admittedly difficult area, the Agreement has achieved even less: the Uruguay Round provisions were weak, and only limited progress has been made in the last five years.

- More positively, many countries have taken advantage of the GATS to create a more secure trading environment by legally binding current levels of openness and some have even precommitted to greater levels of future openness. But the coverage of commitments for developing countries is limited, and in some cases commitments serve to protect the privileged position of incumbents rather than enhance the contestability of markets.

- As befits a multilateral agreement, the GATS in principle prohibits a country from discriminating between its trading partners. The explicit departures from this obligation, such as the exceptions for regional integration agreements and the exemptions listed by Members, are well known. But the difficulties in preventing implicit discrimination through domestic regulations and through the allocation of quotas have not been adequately appreciated.

- Finally, the GATS has so far done little to address the problem of private anticompetitive practices which fall outside the jurisdiction of national competition law, e.g. in sectors like maritime and air transport. It has thus failed to reassure small 
countries that the gains from liberalization will not be appropriated by international cartels.

The rest of this paper develops the arguments presented above, and provides suggestions on possible improvements not only in the rules of the Agreement, but also in the specific commitments made by countries and the negotiating methodology. ${ }^{2}$ Where relevant, the paper draws upon the experience of the East Asian countries with the GATS. A basic tenet of the paper is that it is possible to make improvements in the GATS, and to make it a more effective instrument of liberalization, without fundamental structural changes, which are, in any case, of doubtful political feasibility.

\section{Efficient Protection}

The domestic political economic forces that lead to protection may also dictate that is obtained through inefficient instruments. In goods trade, negotiations helped reduce protection, but ensuring that the efficient instruments of protection were chosen was the role of rules. Thus, GATT rules broadly reflect the ranking of instruments suggested by economic theory: quotas are prohibited, tariffs are allowed but progressively negotiated down and bound, and production subsidies are permitted but subject to countervailing action under certain circumstances. The GATS rules on market access do not create a similar hierarchy. There are two basic rules: the market access provision (Article XVI) simply lists a set of measures, mostly different types of quotas, that cannot be maintained in scheduled sectors unless pre-specified. ${ }^{3}$ And the national treatment provision (Article XVII) prohibits any form of discrimination (including through subsidies) against foreign services and foreign service suppliers again unless pre-specified. ${ }^{4}$ Thus, in the services

\footnotetext{
${ }^{2}$ The paper draws upon other research by the author, in particular Mattoo (2000).

${ }^{3}$ Article XVI stipulates that measures restrictive of market access which a WTO Member cannot maintain or adopt, unless specified in its schedule, include limitations on :

(a) the number of service suppliers;

(b) the total value of services transactions or assets;

(c) the total number of services operations or the total quantity of service output;

(d) the total number of natural persons that may be employed in a particular sector;

(e) specific types of legal entity through which a service can be supplied; and

(f) foreign equity participation (e.g. maximum equity participation).

With the exception of (e), the measures covered by Article XVI all take the form of quantitative restrictions.

${ }^{4}$ Article XVII: 1 states the basic national treatment obligation:
} 
context, both the level and the form of protection are the outcome of negotiations between WTO Members.

\section{Ranking alternative instruments}

The question is: does economic theory in its current state suggest an hierarchy of instruments affecting services trade and is it possible to create rules that favour a choice of superior instruments? The superiority of subsidies over trade restrictions is as valid for services as it is for goods. ${ }^{5}$ And, in principle, tariffs are to be preferred to quotas for much the same reason as in the case of goods. But there are at least three reasons why differences may arise. First, in some instances tariffs may not be easy to impose and so the substitution of a more desirable policy instrument for a less desirable one may not be feasible. Secondly, some of the instruments that have a tariff-like effect in terms of inflicting costs on foreign providers (such as overly burdensome standards), are not however tariff-like in generating revenue. Finally, there are the numerous restrictions imposed on foreign direct investment and the movement of personnel which directly affect the market structure.

Consider each issue ir turn. First, the difficulty of switching to fiscal instruments of protection has probably been exaggerated. As far as cross-border trade is concerned, the imposition of duties is probably most difficult - perhaps impossible, given the current state of technology - when a service is delivered electronically. But in this case, other barriers to trade are also likely to be infeasible. Where quotas are feasible and maintained, as on cross-border trade in transport services, it is easy to conceive of tarifftype instruments: e.g. a tax per passenger or unit of cargo carried by a foreign company.

\footnotetext{
"In the sectors inscribed in its Schedule, and subject to any conditions and qualifications set out therein, each Member shall accord to services and service suppliers of any other Member, in respect of all measures affecting the supply of services, treatment no less favourable than that it accords to its own like services and service suppliers."

Unlike Article XVI, Article XVII provides no exhaustive list of measures inconsistent with national treatment. Nevertheless, Article XVII: 2 makes it clear that limitations on national treatment cover cases of both de jure and de facto discrimination.

${ }^{5}$ Both instruments encourage national production, the former by reducing the private costs of national producers and the latter by imposing a cost on foreign service providers. The latter is an inferior instrument because it leads to a deterioration in the price-quality mix that foreigners are able to provide local
} 
Moreover, the auction of a quota is analogous in economic effect to the imposition of a tariff. In the case of commercial presence, a number of fiscal instruments are possible, including entry taxes (or auctions of entry licenses), output taxes and profit taxes. Ironically, the legal systems of many countries allow discrimination against foreigners through outright bans and entry quotas but make it difficult to impose discriminatory taxes.

Consider now the consequences of restrictive measures that increase foreign costs without generating revenue. In this case, part of the loss in consumer surplus is not offset by an increase in tariff revenue. So the loss in national and global welfare is much greater. Similarly, when quotas are imposed, their consequences for (national) welfare could be alleviated if the rents generated accrued domestically to importers or the government rather than foreign exporters. But the difficulties of intermediation in services suggest that quota-rents are more likely to be appropriated by exporters. Or more likely, quotas are likely to lead to socially wasteful administration costs and rentseeking. Hence, one general conclusion is that if complete liberalization is not feasible, a shift from both quotas and non-revenue generating measures to fiscal measures would lead to an increase in both national and global welfare.

A prohibition of quotas is unlikely to be politically feasible today. An intermediate step would be to build into GATS rules a legal presumption in favour of fiscal measures. ${ }^{6}$ The Uruguay Round Understanding on the Balance-of-Payments Provisions of the GATT 1994 provides a useful model. This Understanding requires Members to give preference to price-based measures and to use quotas only if price-based measures are inadequate, and the choice must be justified. In the GATS context, we would wish to see a shift from both quotas and wasteful discriminatory regulations to fiscal measures. Inducing a shift away from the former would require making the market access provision more stringent. Inducing a shift from latter has not been anticipated in the structure of the Agreement and may be worth considering. In any case, greater flexibility in the national treatment provision (which prohibits all forms of discrimination) is not necessary. For even if a

consumers. See also Hindley and Smith (1984), Hindley (1988) and UNCTAD and World Bank (1994) for a discussion of the economics of services trade. 
country had committed to providing national treatment, then it is allowed to modify its commitments (under Article XXI) and switch instruments of protection - as long as the extent of protectionist does not increase.

\section{Restrictions on FDI}

Restrictions on foreign investment assume particular significance in the case of services where cross-border delivery is not possible, so that the price and quality of the service depend completely on the domestic market structure. Many developing countries, including some of those in East Asia, have been reluctant to allow unimpeded entry; instead market access has been conceded either by allowing limited foreign entry or increased foreign ownership of existing firms. Malaysia, Philippines and Thailand are among the countries that impose equity restrictions and restrictions on entry in key sectors like telecommunications and financial services, while many other East Asian countries have imposed one or the other type of restriction (see Tables 1-3).

A central conclusion of the literature on privatization is that larger welfare gains arise from an increase in competition than from simply a change in ownership from public to private hands. Does the conclusion change when the change of ownership is from national to foreign hands? Foreign investment clearly brings benefits even in situations where it does not lead to enhanced competition (i.e. there are entry restrictions). Foreign equity may relax a capital constraint, can help ensure that weak domestic firms are bolstered (e.g. via recapitalizing financial institutions), and serve as a vehicle for transferring technology and know-how, including improved management. However, if FDI comes simply because the returns to investment are artificially raised by restrictions on competition, the net returns to the host country may be negative (returns to the investor may exceed the true social productivity of the investment). To some extent the rent appropriation may be prevented by profit taxation or by holding competitive auctions of licenses or equity, but the benefits of competition would still not be obtained. ${ }^{7}$

\footnotetext{
${ }^{6}$ See Deardoff (1994), Snape (1994) and Hoekman (1996).

${ }^{7}$ It is also difficult to provide an economic rationale for foreign equity restrictions. The incentive to transfer technology or otherwise to improve performance is bound to be less for foreign investors if they will only receive a fraction of the gain. It would, therefore, be optimal to allow full foreign ownership to
} 
Entry restrictions are becoming harder to justify in the face of growing evidence of the benefits of competition. ${ }^{8}$ Why then do we observe such widespread restrictions on entry? While it is possible to construct special models of market and/or regulatory failure where entry barriers enhance welfare (Laffont, 1999), there are usually more prosaic reasons for the barriers. First, restrictions generally aim to protect the incumbent suppliers from immediate competition for infant industry type reasons, to facilitate "orderly exit" or simply due to political economy pressures. And the result is protection not only of national firms but also foreign incumbents - as in the case of foreign telecom monopolies in Hong Kong, foreign insurance companies in Malaysia, and, most strikingly, the bilateral agreements in air transport. Other instruments, such as discriminatory subsidies or taxes could be better targeted. Monopolistic or oligopolistic rents are also sometimes seen as a means to help firms to fulfil universal service obligations through cross-subsidization. However, governments are increasingly devising means of achieving these objectives without sacrificing the benefits of competition: e.g. by imposing universal services obligations on new entrants or asking for competitive bids for subsidies to serve unprofitable areas. In some cases, a form of "investment pessimism" exists, leading to the belief that promises of oligopoly rents are necessary to attract new investment. However, it is not clear why the market structure needs to be determined by policy, unless there are some initial investments the benefits of which may be appropriated by rivals. Finally, governments may seek to raise revenue (or rents for politicians/bureaucrats) by auctioning monopoly or oligopoly rights. This amounts to indirect appropriation of consumers' surplus. But the static and dynamic inefficiencies consequent upon lack of competition would still exist.

Ideally, multilateral rules should make it difficult for governments to resort to trade restrictions to pursue objectives which are better achieved through other means. In each of the cases mentioned above, entry restrictions are at best a second or third-best

prevent dilution of incentives, and extract potential rents through the initial sale price. However, political concerns about foreign control probably account for the broad ownership restrictions in countries like Malaysia and the Philippines, and in the incumbent firm in the telecom sector in Japan.

${ }^{8}$ In Latin America, for example, countries that granted monopoly privileges to telecom operators of six to ten years to the privatized state enterprises saw connections grow at 1.5 times the rate achieved under state monopolies but only half the rate in Chile, where the government retained the right to issue competing licenses at any time. 
instrument to achieve the objective in question, but are chosen because of constraints such as the inability to raise revenue without economic or political cost. It will probably be difficult and not necessarily desirable to outlaw completely barriers to entry. But it may be possible to create a legal presumption against such barriers by requiring that a country which imposes them demonstrate that they are necessary - in the sense that more appropriate instruments are not feasible. This idea is developed below.

\section{Credibility through GATS commitments}

It is well known that the freedom to change one's mind can be a nuisance. The GATS offers a valuable mechanism to make credible commitments to policy. Failure to honour these commitments would create an obligation to compensate those who are deprived of benefits, making the commitment more credible than a mere announcement of liberalizing intent in the national context. Governments can bind current policy or commit themselves to implement liberalization at a future date.

Unfortunately, with some exceptions, not much was made of this opportunity. In general, countries made limited commitments, excluding many sectors and many modes. ${ }^{9}$ The larger East Asian economies did bind a certain level of access in segments of major services sectors like business, communication, financial, transport and tourism, but few countries made commitments in sectors like distribution, education, environmental and health services. Several countries in the region bound at less than the status quo, at least with respect to some aspects of their regimes. The Philippines, for example, did so with respect to foreign equity participation in commercial banks: binding at $51 \%$ when domestic law allows $60 \%$. The Republic of Korea also stopped short of reflecting in its GATS offer all the present and future liberalization commitments made at the OECD. ${ }^{10}$

\section{Precommitment}

\footnotetext{
${ }^{9}$ See Hoekman (1996) and Adlung (2000).

${ }^{10}$ Furthermore, under the terms of the IMF agreement, the de facto regime with respect to foreign capital is already more liberal than the GATS offer. For instance, president Kim Dae-Jung was quoted as saying that "From now on there is no need for discrimination between indigenous and foreign capital. We are living in an era where foreign investment is more important than foreign trade." (Financial Times, 29 December 1997).
} 
One reason governments may be reluctant to liberalize immediately is a perceived need to protect the incumbent suppliers from competition-either because of infant industry type arguments or to facilitate "orderly exit." The failure of infant industry policies in the past, and the innumerable examples of perpetual infancy, is attributable in part to the inability of a government to commit itself to liberalize at some future date and hence to confront incumbents with a credible deadline. One way of overcoming the credibility problem is for governments to make binding commitments under the GATS to provide market access at a precise future date.

In general, the use of the GATS as a mechanism for lending credibility to future liberalization programmes has been disappointing. But the telecommunications sector is an exception. In this sector, several East Asian governments are among those who have taken advantage of the GATS to strike a balance between their reluctance to unleash competition immediately on protected national suppliers and their desire not to be held hostage in perpetuity either to the weakness of domestic industry or to pressure from vested interests (Table 1). Singapore and the Republic of Korea have bound themselves to introduce competition at precise future dates. Indonesia and Thailand are among the countries that have made weaker commitments. Greater use needs to be made of the GATS in this respect for there is growing evidence that reform programmes that are believed are more likely to succeed.

\section{Grandfather Provisions}

A particularly perverse use of commitment from an economic point of view is the inclusion of grandfather provisions in the financial services schedules of some countries under negotiating pressure. The issue arose because domestic law, pertaining to foreign ownership, branching and other rights, had changed since foreign firms first established commercial presence. For instance, Malaysia began to implement its indigenization policy after several fully foreign-owned firms were already operating in its market. The home countries of the firms were unwilling to see a dilution of what they saw as "acquired rights" whereas Malaysia was unwilling to grant the same rights to new 
entrants. The negotiated solution was for Malaysia to commit to preserve the rights of incumbents while offering inferior terms to new investors. Where differences in ownership and legal form affect firm performance, new entrants have been placed at a competitive disadvantage. Thus, the triumph of moral over economic reasoning has meant that the GATS was used to make markets less contestable.

\section{Regulatory disciplines}

Most of the key regulatory challenges must necessarily be addressed at the national level, and even more than in the case of other policies, there are limits to what should and can be addressed at the multilateral level. Still there are likely to be benefits from strengthened multilateral disciplines on domestic regulations. First of all, such disciplines are needed to enable exporters to address regulatory barriers to their exports in foreign markets. For instance, unless disciplines are developed to deal with licensing and qualification requirements, market access commitments in areas like financial and professional servics will have only notional value. Furthermore, the development of such disciplines can play a significant role in promoting and consolidating domestic regulatory reform. The telecommunications negotiations, which led to the early institution of independent regulators in many countries, provide an example of this possibility. Finally, there is a class of problems that must necessarily be addressed at the multilateral level: the problem of international cartels in sectors like maritime transport.

\section{The case for a horizontal approach}

One of the ironies of the GATS is that among its weakest general provisions are those dealing with domestic regulations. ${ }^{11}$ The reason is not difficult to see: it is extremely difficult to develop effective multilateral disciplines in this area without seeming to encroach upon national sovereignty and unduly limiting regulatory freedom.

Nevertheless, it is desirable and feasible to develop horizontal disciplines for domestic

\footnotetext{
${ }^{11}$ The relevant provision (Article VI) requires Members not to apply licensing and qualification requirements and technical standards so as to undermine market access commitments in a manner "which could not reasonably have been expected" when the specific commitments were made. This provision may
} 
regulations. $^{12}$

Such a generic approach is to be preferred to a purely sectoral approach for at least three reasons: it economizes on negotiating effort, leads to the creation of disciplines for all services sectors rather than only the politically important ones, and reduces the likelihood of negotiations being captured by sectoral interest groups. It is now widely recognized that the most dramatic progress in the EU single-market programme came from willingness to take certain broad cross-sectoral initiatives. In the WTO context, the experience of the accountancy negotiations shows the propensity for single sectoral negotiations on domestic regulations to produce a weak outcome: while a valuable "necessity test" was instituted, the elaboration of disciplines on measures such as qualification requirements was disappointing.

Even if a horizontal approach is desirable, is it feasible? The diversity of services sectors, and the difficulty in making certain policy-relevant generalizations, would seem to favour a sector-specific approach. However, even though services sectors differ greatly, they have much in common in terms of the underlying economic and social reasons for regulations. And focusing on these reasons provides the basis for the creation of meaningful horizontal disciplines. The economic case for regulation in all services sectors arises essentially from market failure attributable primarily to three kinds of problems, natural monopoly or oligopoly, asymmetric information, and externalities.

\section{Dealing with domestic monopolies}

Market failure due to natural monopoly or oligopoly may create trade problems because incumbents can impede access to markets in the absence of appropriate regulation. Because of its direct impact on trade, this is the only form of market failure that may need to be addressed directly by multilateral disciplines. The relevant GATS provision, Article VIII dealing with monopolies, is limited in scope. As a consequence, in the context of the telecom negotiations, the Reference Paper with its competition principles was developed

provide a defence against new restrictions but could be interpreted to mean that old regulations whose persistence could reasonably have been expected cannot be challenged.

${ }^{12}$ See also Feketekuty (2000). 
in order to ensure that monopolistic suppliers would not undermine market access commitments (Tuthill, 1997). It might be possible to generalize these principles to a variety of other network services, including transport (terminals and infrastructure) and energy services (distribution networks), by ensuring that any major supplier of essential facilities provides access to all suppliers, national and foreign, at cost-based rates. ${ }^{13}$

\begin{tabular}{|l|l|l|}
\hline Market failures & Services sectors & Multilateral approach \\
\hline $\begin{array}{l}\text { Monopoly/ } \\
\text { oligopoly }\end{array}$ & $\begin{array}{l}\text { Network services: transport } \\
\text { (terminals and infrastructure), } \\
\text { environmental services } \\
\text { (sewage) and energy services } \\
\text { (distribution networks). }\end{array}$ & $\begin{array}{l}\text { Generalize key disciplines in } \\
\text { telecom reference paper to } \\
\text { ensure cost-based access to } \\
\text { essential facilities, be they roads, } \\
\text { rail tracks, terminals, sewers or } \\
\text { pipelines. }\end{array}$ \\
\hline $\begin{array}{l}\text { Asymmetric } \\
\text { information }\end{array}$ & $\begin{array}{l}\text { Intermediation and knowledge } \\
\text { based services: financial } \\
\text { services, professional } \\
\text { services, etc. }\end{array}$ & $\begin{array}{l}\text { Non-discrimination and } \\
\text { generalization of the "necessity" } \\
\text { test. Use the test to create a } \\
\text { presumption in favour of } \\
\text { economically efficient choice of } \\
\text { policy in remedying market } \\
\text { failure. }\end{array}$ \\
\hline $\begin{array}{l}\text { Externalities } \\
\text { Social objectives: } \\
\text { Universal service }\end{array}$ & $\begin{array}{l}\text { Transport, tourism, etc. } \\
\text { telecommunications, } \\
\text { financial, education, health }\end{array}$ & \\
\hline
\end{tabular}

Other sources of domestic market failure

In all other cases of market failure, multilateral disciplines do not need to address the problem per se, but rather to ensure that domestic measures to deal with the problem do not serve unduly to restrict trade. (The same is true for measures designed to achieve social objectives.) Such trade-restrictive effects can arise from a variety of technical standards, prudential regulations, and qualification requirements in professional, financial and numerous other services; as well as from the granting of monopoly rights to complement universal service obligations in services like transport and telecommunications. The trade-inhibiting effect of this entire class of regulations is best disciplined by complementing the national treatment obligation with a generalization of the so-called "necessity" test. This test leaves governments free to deal with economic and social problems provided that any measures taken are not more trade restrictive than

\footnotetext{
${ }^{13}$ Even though it would be extremely difficult to determine what cost-based rates are, the provision should
} 
necessary to achieve the relevant objective. The test is already applied to technical barriers to trade in goods, and is part of the recently established "pilot" disciplines for the accountancy sector. It might make sense to go beyond the GATT precedent, and to use the test to create a presumption in favour of economically efficient choice of policy in remedying market failure and in pursuing non-economic objectives. ${ }^{14}$ For instance, in the case of professionals like doctors, a requirement to re-qualify would be judged unnecessary, since the basic problem, inadequate information about whether they possess the required skills, could be remedied by a less burdensome test of competence.

The necessity test is generally seen as an additional discipline on non-discriminatory measures. It has not been recognized that without some such test it would be difficult to apply even the fundamental disciplines of national treatment (Article XVII) and MFN (Article II) - for it would be impossible to determine if a measure is in effect nondiscriminatory. ${ }^{15}$ Both Articles prohibit discrimination between like services and like service suppliers but likeness itself is not easy to establish. If a doctor is a doctor, a regulation that imposed any additional burden on a doctor trained in Country A (abroad) than on a doctor trained in Country B (at home) would violate Article II (Article XVII). If a doctor trained in one country is deemed to not be "like" a doctor trained in another country, then the disciplines contained in the Articles would simply not apply. The former interpretation may be unduly stringent and politically unsustainable, the latter is unduly permissive and would open the door to all manner of regulatory protection. The necessity test would seem to be the perfect solution. Countries are not prevented from imposing additional qualification and training requirements but these should not be more burdensome than necessary, in the sense described above.

To conclude, the arguments in this section must not be taken to mean that there is no need for sector-specific work. Such work is necessary, and should involve consumers, industry and regulators, to help determine how best to deal with asymmetric information and differences in standards between countries in particular sectors. But the application of a necessity test is necessary today because harmonization and mutual recognition are

at least make it possible to challenge the more egregious departures.

${ }^{14}$ Mattoo and Subramanian (1998). 
not meaningful alternatives - even though they can play a role at the regional or plurilateral level. The pessimism with regard to harmonization is based on the absence of widely accepted international standards in services. Where such standards exist, as in banking or maritime transport, meeting them is seen as a first step towards acceptability, rather than as a sufficient condition for market access. With regard to mutual recognition agreements (MRAs), it would seem that even in strongly integrationist Europe, despite a significant level of prior harmonization, the effect of MRAs may have been limited by the unwillingness of host country regulators to concede complete control. ${ }^{16}$

Competition policy: the international dimension

The pro-competitive rules developed for the basic telecommunications sector were designed to protect the rights of foreign suppliers. Is there a need for broader competition policy disciplines in the GATS to protect the interests of consumers more directly? Article IX of the GATS deals with "certain business practices of service suppliers, other than those falling under Article VIII, [which] may restrain competition and thereby restrict trade in services". But its disciplines are weak, and require little more than consultation and information sharing.

There may be a need to strengthen these disciplines. Consider one particularly important example. Maritime transport costs have a profound influence on international trade. Their persistent high level has been attributed not only to restrictive trade policies, but also to private anti-competitive practices such as rate-binding agreements, primarily but not exclusively of the maritime conferences. ${ }^{17}$ The high incidence of such agreements is due to the fact that the United States, the European Union and many other countries exempt shipping conferences from antitrust regulation - on the ground that they provide price stability and limit uncertainty regarding available tonnage. In the case of routes

\footnotetext{
${ }^{15}$ There is no explicit mention of the necessity test in the national treatment and MFN provisions.

${ }^{16}$ Nicolaidis and Trachtman (1999).

${ }^{17}$ Hummels (1999).
} 
serving the United States, the exemption from antitrust law is compounded by the Federal Maritime Commission's (FMC) role in helping police price-fixing arrangements. ${ }^{18}$

A recent econometric analysis suggested that while public restrictions adversely affect maritime transport costs, private anti-competitive practices have an even stronger impact. ${ }^{19}$ Thus, it would seem that even though there has been an erosion in the power of conferences due to the entrance in the market of efficient outsider shipping companies and of a certain tightening in the law, collusive arrangements have not disappeared. ${ }^{20}$ As recently as May this year, the European Commission imposed fines on shipping lines serving the East Asian and US routes and on those serving the transatlantic route for collusive pricing which went beyond the scope of the exemptions that had been granted.

What are the implications for policy? The negotiations on maritime transport were the only post-Uruguay round services negotiations that completely failed. This failure implied an unfortunate loss of political momentum for reform of domestic policies, and, less obviously, a lost opportunity to develop pro-competitive rules. To some extent, an effort was made to develop rules that would ensure non-discriminatory access to port services. $^{21}$ But these rules, concerned primarily with ensuring market access, did little to protect consumers from the anti-competitive practices of international cartels. An international initiative is needed, since these practices cannot be adequately addressed only through national competition policy-given the weak enforcement capacity of small states. A further reason for developing a first-best international response to these practices is to prevent recourse to an inferior national response: recall that the costly

\footnotetext{
${ }^{18}$ The 1984 US Shipping Act required all ocean carriers to file their rates with the FMC and publish their rate and schedule information. Secret discounting on filed rates was until recently considered illegal. The FMC was authorized to ensure, through the imposition of fines, that the filed rates were actually charged. The rationale for these measures was ostensibly to protect small shippers from being disadvantaged by their inability to extract discounts from shipping companies.

${ }^{19}$ Fink, et al. (2000) estimate that the break-up of conference and other price-setting agreements leads to a more dramatic reduction in transport prices ( 38 percent) than restrictive cargo allocation policies (11 percent). The estimated potential savings from the elimination of both could be as high as one billion U.S. dollars on goods carried to the US alone.

${ }^{20} \mathrm{~A}$ recent change in US regulation regarding international shipping, notably the Ocean Shipping Reform Act (OSRA) of 1998, allows for the confidentiality of key terms (prices are included in this category) in contracts between shippers and carriers but preserves the antitrust immunity of the rate-setting conference system.

${ }^{21}$ In some respects, the approach to port services, which can be seen as "essential facilities" often controlled by "major" or monopoly suppliers, was analogous to the approach to basic telecommunications networks established in the regulatory principles referred to above.
} 
cargo-sharing schemes imposed by many developing countries were primarily a reaction to the perceived power of conferences.

One approach would be to deal with the problem by creating sector-specific competition rules, as has been attempted in basic telecommunications services under the GATS. However, if there is sufficient evidence that anti-competitive practices also affect other services sectors, such as air transport and communications, there may a need to strengthen the general GATS disciplines, i.e. Article IX dealing with anticompetitive business practices. ${ }^{22}$ This would serve to reassure small countries in particular that the gains from liberalization will not be eroded by collusive pricing.

\section{The Most-Favoured Nation Principle}

The GATS and its MFN obligation came into effect before WTO Members were willing to eliminate completely discriminatory measures in services trade. The Agreement therefore had to strike a difficult balance between creating meaningful multilateral disciplines and accommodating discriminatory trade practices. The challenge to multilateral disciplines posed by the explicit departures from the MFN obligation, such as the exceptions for regional integration agreements and the MFN exemptions listed by Members, are widely recognized. However, the difficulties arising from less visible, implicit discrimination have not been adequately appreciated.

The scope and significance of explicit departures from $M F N$

Consider the explicit exemptions first. Around $380 \mathrm{MFN}$ exemptions have been listed by some 70 Members, with many Members listing several exemptions in the same sector. ${ }^{23}$ Nearly two-thirds of the exempted measures are to be found in communication services and in transport services. One reason specified for these measures is the existence of sector-specific preferential regional agreements, or other bilateral or plurilateral agreements. For instance, in audiovisual services, more than half of the exemptions

\footnotetext{
${ }^{22}$ It is also conceivable that these issues could be addressed as part of broader competition policy disciplines in the WTO.
} 
mention promotion of common (regional) culture as a motive for limiting access to joint programmes to finance and diffuse audiovisual works; and in maritime transport, nearly half the exemptions are by developing countries for measures implementing the provisions of the United Nations Convention on a Code of Conduct for Liner Conferences. $^{24}$ The other reason cited for exemptions is a unilaterally imposed reciprocity condition - which specifies that a Member is willing to guarantee access to its market only to those Members who provide it with access to their markets. These are particularly significant in air transport services and financial services. ${ }^{25}$

In cases where the exemptions coexist with specific commitments (as in financial services) ${ }^{26}$ or legitimize preferences which do not greatly affect the pattern of trade (as in cross-border supply of land transport services), there is probably not much cause for concern. MFN exemptions would seem to matter most, and be most difficult to eliminate, in sectors like audiovisual services and maritime transport where few specific commitments have been made and discriminatory practices seem to be empirically important.

Perhaps even more important than the MFN exemptions that have been listed are those that did not need to be. The Annex on Air Transport specifically excludes the complex network of bilateral agreements on air traffic rights from GATS rules. ${ }^{27}$ Thus, a sector that is in urgent need of liberalization remains fragmented into cozy duopolies, and prospects for progress at the multilateral level are dim. One source of hope is the increasing agreement among WTO Members to push for the liberalization of a cluster of

\footnotetext{
${ }^{23}$ See Table 1 in Mattoo (2000).

${ }^{24}$ These provisions, in principle, divide 80 per cent of the liner trade on a traffic route between the shipping companies of the two states at each end, leaving only 20 per cent for shipping companies of other nationalities. Full implementation of this rule is apparently rare, and third country ships usually have access to a larger share of the market. Many Members chose to maintain MFN exemptions despite the suspension of the obligation for the sector.

${ }^{25}$ The exemptions listed for air transport services pertain to the services falling within the scope of the GATS, i.e repair and maintenance, selling and marketing of air transport services, and computer reservation system (CRS) services.

${ }^{26}$ Market access guaranteed under specific commitments must be extended on a non-discriminatory basis to all trading partners - even if an MFN exemption has been sought. The MFN exemption can provide legal cover only for better treatment for some trading partners than provided for in the specific commitments.

${ }^{27}$ International air transport services are for the most part governed by arrangements negotiated under the Chicago Convention (i.e. the International Air Services Transit Agreement, done at Chicago, 7 December 1944.)
} 
services related to tourism. Excluding air transport from this initiative would be like leaving the Prince of Denmark out of a certain play.

The US exemption in maritime transport was more like Banquo's ghost: it was not explicitly listed - because the MFN obligation was suspended for the sector - but had a completely disruptive effect on the negotiations. ${ }^{28}$ The US did not believe that the quality of its trading partners' market-opening commitments justified giving up its right to take retaliatory action against foreign restrictive practices. One way of making progress in the current round is to bundle transport negotiations together and focus on the liberalization of multimodal transport, a central concern of US industry. Also, the development of competition disciplines, along the lines suggested above, would help to address the anticompetitive practices that the US believes impede access to foreign markets.

The other main departure from MFN is the provision (Article V) for economic integration agreements, which allows any subset of WTO Members to liberalize trade in services among themselves under certain conditions. This provision is broadly modeled on the corresponding provision in the GATT. The agreements which have been notified so far include those establishing NAFTA, the European Communities and their Member States, as well as their agreements with the Slovak Republic, Hungary, Poland, the Czech Republic, Romania, Norway, Iceland, Liechtenstein and Bulgaria, and agreements between Canada and Chile and between Australia and New Zealand. ${ }^{29}$ A discussion of the significance of these agreements and the possible reform of the relevant GATS rules is beyond the scope of this paper. ${ }^{30}$

\footnotetext{
${ }^{28}$ The original US MFN exemption for maritime transport services reserved the "right to investigate and take action against foreign carriers to address adverse or unfavourable actions affecting US shipping or US carriers in US oceanborne commerce and the cross trades between foreign ports".

${ }^{29}$ A related exception from the MFN rule, for the movement of natural persons, is permitted by Article $V$ bis of the GATS. This allows countries to take part in agreements which establish full integration of labour markets. The only such agreement notified so far is the one involving Denmark, Finland, Iceland, Norway and Sweden.

${ }^{30}$ See Stephenson (2000).
} 


\section{Discrimination through domestic regulations and quotas: economic considerations}

The consequences of discrimination between trading partners through taxation (or duties) are well understood. Does discrimination through domestic regulations and quotas raise new analytical issues from the economic and legal point of view?

When tariffs are the instruments of protection, the costs of trade diversion for the importing country may be an important deterrent to preferential liberalization agreements. Despite the increase in consumers' surplus from any liberalization, governments may nevertheless be averse to such agreements because the displacement of high-tariff imports from third countries by low or no-tariff imports from preferential sources implies lost revenue. The same reasoning also applies to other regulations which imply a transfer from foreign suppliers to domestic interest groups. However, the situation is different when the protectionist instrument is a regulatory barrier which imposes a cost on the exporter without yielding a corresponding revenue for the importing government or other interest group. There is then no cost to the country granting preferential access because there is no revenue to lose. The same is true in the case of quotas where the rents were either dissipated or appropriated by foreign suppliers. Therefore, in these cases, preferential liberalization is necessarily welfare enhancing for the importing country - as well as for the exporting country which obtains improved access. $^{31}$

However, if third countries supply the market in question, they lose because prices decline due to increased sales from the preferred source. The impact on global welfare depends on the nature of regulatory measure. If it generates no revenues or rents, then global welfare will increase. In effect, exempting some suppliers from the measure reduces their costs and leads to a reduction in price in the importing country. The gain to consumers from any decline in price is necessarily greater than the loss to a subset of suppliers. This suggests that multilateral rules should take a more tolerant view of preferential arrangements like recognition agreements that help eliminate wasteful

${ }^{31}$ This reasoning does not take account of the fact that there may be greater spill-over benefits (e.g. relating to technology) arising from trade with certain partners than with others. 
duplication (e.g. of training) and are therefore global welfare-enhancing. But we must not lose sight of the fact that non-preferential liberalization would enhance welfare even more because the service would be supplied by the most efficient locations.

\section{Legal considerations}

\section{Recognition agreements}

Recognition agreements are like sector-specific preferential arrangements, and can have similar trade-creating trade-diverting effects. Their result may well be to create trade according to patterns of mutual trust rather than the pattern of comparative advantage. The interpretation of the GATS provision on recognition (Article VII) is, therefore, likely to be of considerable importance. The provision attempts to strike a difficult balance.

On the one hand, it is permissive and allows a Member at any point of time to recognize the standards of one or more Members and not of others. On the other hand, it seeks to ensure that this freedom is not abused by prohibiting the use of recognition as a means of discrimination and requiring a Member who enters into a recognition agreement (RA) to afford adequate opportunity to other Members to negotiate their accession to such an agreement or to negotiate comparable ones. In this respect, Article VII mandates an openness vis-à-vis third countries in a way that Article $\mathrm{V}$, dealing with economic integration agreements, does not. ${ }^{32}$

How can it be established whether acceptance of some standards and not others is discriminatory? The approach discussed with regard to domestic regulations is also applicable here. Making distinctions between services and service suppliers in the pursuit of certain domestic policy objectives, such as to ensure the quality of professional services, financial stability, and competitive market conditions, is economically sensible.

\footnotetext{
${ }^{32}$ Article V on integration agreements does not explicitly preclude RAs, and several countries (Such as Australia and New Zealand) have chosen to notify their RAs under this provision. It would seem desirable to establish that Article VII, with its desirable non-discriminatory and open-ended nature, overrides Article $V$ of the GATS as far as RAs are concerned. This interpretation would help to generalize the liberalizing impact of RAs - for while an RA amounts to an acceptance of likeness vis-à-vis suppliers from a particular country, it also defines the appropriate standard of treatment vis-à-vis suppliers from other countries.
} 
It would, therefore, be desirable to allow Members the legal freedom to pursue such objectives, but to discipline the exercise of such freedom by ensuring that the choice and level of instruments is not more burdensome than necessary - with economic efficiency considerations playing a role in this assessment. The text of Article VII does not contain an explicit necessity test but, as in the case of the MFN and national treatment obligations, it is difficult to see how the provision can be given meaningful content without the inclusion of such a test.

Non- discriminatory allocation of quotas

One central legal issue in the GATS, which has received surprisingly little attention, is how quotas are to be allocated in a manner consistent with the non-discrimination obligation. In the past, this was not a major issue because commitments reflected the status quo and the quotas, particularly with regard to service suppliers, were descriptions of the existing market structure. ${ }^{33}$ But in the future, as genuine liberalizing commitments are made, the non-discriminatory allocation of quotas is bound to be an important issue. For instance, it has been reported that China, as part of its accession negotiations, promised the European Union that is firms would be granted a specific number of licenses in the insurance sector. How is this assurance to be reconciled with the MFN obligation?

The goods precedent offers limited guidance. GATT Article XIII, on the "nondiscriminatory administration of quantitative restrictions", requires aiming at a distribution of trade approximating the shares which countries might be expected to have in the absence of such restrictions or supplied during a previous representative period. In the services context, the requirement to replicate historical shares may have no relevance if there was no previous foreign presence, or perpetuate historical discrimination if previous quotas were allocated to favoured suppliers. ${ }^{34}$

\footnotetext{
${ }^{33}$ Thus when Bangladesh committed to "four licenses issued" in cellular telephony, the ambiguity in the choice of tense was not an accident: the licenses in question had already been issued.

${ }^{34}$ In the Bananas Case, the European Union's method of allocating import licenses for bananas from certain sources was found to be inconsistent with Article II because it reallocated quotas and quota rents away from the importers who traditionally imported from these sources (see paragraphs 7.350-7.353 of the Panel Report). In a sense, the Panel's reasoning followed the logic of GATT Article XIII.
} 
More appropriate candidates for a non-discriminatory allocation of quotas would seem to be first-come, first-served rule (e.g. where a large number of work permits are being issued) or a system of auctions to the highest bidder (e.g. where a few telecom licenses are being issued). Neither rule would necessary lead to distributions "which ... might be expected to obtain in the absence of such restrictions. "35 It would seem, therefore, that the rules for ensuring non-discriminatory allocation of quotas under GATS would need to look beyond the GATT-precedent. It is possible that a less elaborate variant of the disciplines in the Agreement on Government Procurement, designed to ensure competitive tendering on a non-discriminatory basis, will need to be considered.

\section{Reviving Reciprocity?}

Reciprocity has been a central principle governing GATT/WTO negotiations: one country reduces its level of protection in return for a reciprocal reduction by its trading partner. $^{36}$ While reciprocity-based negotiations are widely credited with the substantial reduction in levels of protection achieved in goods trade, it is surprising that the limited application of the principle has not conversely been seen as the reason for the disappointing results in services trade.

The General Agreement on Trade in Services (GATS) had a deliberately symmetric structure. In principle, there was scope for developed and developing countries to exploit their modal comparative advantage: improved access for capital from developed countries being exchanged for improved temporary access for individual service providers from developing countries. In practice, there was little political will to improve

\footnotetext{
${ }^{35}$ It is obvious that first-come, first-served favours the proximate. Auctions would give the relatively efficient producers larger shares than they would have obtained in the absence of quotas (when quotas are set at below unrestricted trade levels). Jackson (1991, p. 140), however, notes that first-come, first served and auctions would seem to fulfil the MFN obligation, and refers to the Article XIII reliance on historical patterns as a "quasi" MFN principle.

${ }^{36}$ This emphasis on achieving a "balance of (liberalizing) concessions" has led to the perception of WTO negotiations as a mercantilist process driven by political forces that nevertheless leads to the desirable outcome of reduced levels of protection. In an important recent paper, Bagwell and Staiger (1999) show that reciprocity can be given a more positive economic interpretation: it serves to neutralize the adverse terms of trade effects associated with unilateral reductions in protection, and therefore leads to greater liberalization.
} 
access for foreign individuals (except for the limited class of skilled intra-corporate transferees), and a trade-off between modes of delivery simply did not take place. Moreover, even the negotiating links across services sectors and between services and goods sectors do not seem to have been particularly fruitful. So the GATS commitments reflect for the most part the existing levels of unilaterally determined policy rather than liberalization achieved through a reciprocal exchange of "concessions".

It might well be that reciprocity cannot and will not play a major role in services trade. Services liberalization could for the most part be undertaken unilaterally and the GATS would be important only in preventing its reversal - i.e. in its credibility role. ${ }^{37}$ Indeed, for countries that are either determined to liberalize or determined to protect, negotiations are not important. However, for countries in the middle ground, who are open to reform but whose ability to implement reform is constrained by domestic opposition, multilateral negotiations can be useful. Many developing countries are today in this situation. Furthermore, with severe shortages of skilled labour in the US and Europe and the powerful constituency of high-technology companies lobbying for relaxation of visa limits, the prospects for serious inter-modal trade-offs - such as obtaining labor movement in return for allowing greater commercial presence for foreign service providers - are now greater. And a wider application of the principle of reciprocity may deliver greater liberalization and more balanced outcomes.

\section{Facilitating reciprocity across modes}

A collective commitment to the use of appropriately designed formulae offers the best chance of linking different modes of delivery. ${ }^{38}$ Such formulae can also help overcome concerns about free-riding that arise in an MFN-based system. But is it technically feasible to link concessions across modes? $?^{39}$ One simple option is to take advantage of the current political pressure for accelerated liberalisation in selected sectors, such as

\footnotetext{
${ }^{37}$ See Hoekman and Messerlin (2000).

${ }^{38}$ Developing countries have resisted this option - preferring the use of a request-and-offer approach. Their reluctance stems from defensive considerations and a belief that they would be obliged to concede excessively high levels of openness if a formula approach were adopted.

${ }^{39}$ See Sapir (1998) and Thompson (2000).
} 
environmental services. This approach could be accepted on the condition that there was no gerrymandering: i.e. all countries would liberalise access in all modes including the movement of individuals. Environmentalists and environmental service exporters could then be relied on to counter the opposition of employees and individual suppliers in the domestic environmental industry.

An alternative way of creating a link between modes is by requiring each country to provide increased "foreign labour content entitlements" to its domestic firms in relation to the country's increased exports of services. ${ }^{40}$ Entitlements would be global rather than bilateral, and the extent and pattern of use would be determined by sound economic considerations of modal comparative advantage. Some of the social and political difficulties could be overcome by clarifying that liberalization is only with respect to temporary movement of service suppliers, and does not imply migration. Establishing clear links between increased exports and increased foreign labour content entitlements may also help make the political case. The presence of foreign workers would be seen as a direct consequence of increased opportunities for export abroad, and also as contributing to the increased competitiveness which makes it possible to exploit these opportunities.

\section{Reciprocity within modes across sectors}

It would be wrong to suggest that reciprocity must necessarily take an inter-modal form. There may, for instance, be scope for cross-sectoral reciprocity in the same mode. Trade in electronically delivered products - falling within the scope of cross-border supply - is of growing importance and offers an increasingly viable alternative to the movement of individuals. If the United States can supply financial and audiovisual services to the Philippines electronically, the Philippines in turn can supply software development and data-processing services to the United States. Fortunately most electronic commerce is already free of barriers, and so the main concern should be preventing the introduction of new barriers if they ever become technically feasible. WTO Members have so far focussed on prohibiting the imposition of customs duties on electronically delivered 
products. Since the bulk of such commerce concerns services, open trading conditions are more effectively secured through deeper and wider commitments under the GATS on cross-border trade regarding market access (which would preclude quantitative restrictions) and national treatment (which would preclude all forms of discriminatory taxation). ${ }^{41}$ One possible formula would be for all Members to agree that no restrictions would be imposed on cross-border delivery, either of all services or of a bundle of whose composition could be negotiated.

\section{Remedying the hold-back problem through a credit rule}

One undesirable aspect of an emphasis on reciprocity is that it creates the temptation to hold back from unilateral liberalization. This is why most economists view reciprocity with suspicion. This hold-back problem can be overcome, however, by rules which create an ex ante assurance (at the end of a round of negotiations) that credit would be given in future rounds of negotiations for unilateral liberalization undertaken between rounds. The impulse to liberalize unilaterally then need not be inhibited by the fear of loss of negotiating coinage. The proposed rule is different from the demands for credit which are typically made at the beginning of a new round of negotiations. The acceptance of such demands would have only a distributional effect, favouring those who have already undertaken liberalisation, and the granting of such credit relies on the unlikely generosity of those who have not liberalised. The proposed ex ante assurance of credit rule has three virtues: $:^{42}$ it would help induce and/or enhance liberalisation in some countries between negotiating rounds; more strikingly, it could also lead to deeper levels of multilateral liberalisation and force other countries to go further than in the absence of a rule; and most importantly, such a rule does not rely on altruism to be generally acceptable.

\footnotetext{
40 Mattoo and Olarreaga (2000).

${ }^{41}$ There is considerable scope for an improvement in commitments. For instance, in software implementation and data processing, of the total WTO Membership of over 130, only 56 and 54 Members, respectively, have made commitments; and only around half of these commitments guarantee unrestricted market access, and a similar proportion guarantee unqualified national treatment. It is particularly striking that in the core banking services where around 75 WTO Members have made commitments, about a third of the developing countries guarantee unrestricted cross-border supply whereas only 1 out of the 10 developed countries does so.

42 The alternative rules are discussed more fully in Mattoo and Olarreaga (2000).
} 
GATS Article XIX:3 requires that in each future round "modalities shall be established" for the treatment of liberalisation undertaken autonomously by Members since previous negotiations. In principle, this is precisely the type of ex ante assurance of credit that would be desirable. But the nebulousness of the provision and the postponement of the establishment of modalities suggest that in practice the provision may provide little more than a basis for ex post demands for credit. One way of giving the rule operational content is by establishing that any agreed liberalizing formula would be applied not to current actual levels of protection but to the levels bound in the previous round of negotiations. ${ }^{43}$

\section{Conclusions}

"Reveal and bind all trade-restricting measures." "Make national treatment a general obligation." It would be tempting to make such clear and powerful proposals. But it would not be realistic or useful. The GATS is here to stay in its present form and radical reform will not occur in this round of negotiations - nor probably in the next. Those who think that this is unduly conservative, need only take a closer look at the negotiations in the Working Party on GATS rules. The results of five years work on subjects such as safeguards, subsidies and government procurement are no more tangible than the emperor's new clothes.

It seemed more constructive, therefore, to take a close look at the existing provisions of the Agreement and make precise proposals on how they can be improved. The main conclusions are the following:

- Wasteful regulations and entry restrictions pervade services trade. Unlike the GATT, the GATS has created no hierarchy of instruments of protection - although the analysis here suggests that the ranking of instruments in the case of both goods and services is similar. While it may not yet be politically feasible to impose the same

\footnotetext{
${ }^{43}$ This suggestion was in fact contained in a proposal from Brazil submitted just before the Seattle Ministerial.
} 
hierarchy as in goods, an attempt should nevertheless be made to create a legal presumption in favour of instruments (such as fiscal measures) that provide protection more efficiently.

- Greater advantage must be taken of the valuable opportunity offered by the GATS to lend credibility to reform programmes by committing to maintain current levels of openness or by precommitting to greater levels of future openness.

- Multilateral rules on domestic regulations can play an important role in promoting and consolidating domestic regulatory reform, even when they are primarily designed to prevent the erosion of market access commitments. It would be desirable to generalize the application of pro-competitive principles developed for basic telecommunications to other network-based services sectors, and the application of the "necessity test" instituted for accountancy services to regulatory instruments in all sectors.

- Anticompetitive practices could be important in sectors like maritime, air transport and communication services. Since these practices cannot be adequately addressed through national competition policy-given the weak enforcement capacity of small states -GATS rules in this area must be strengthened.

- Explicit departures from the MFN rule matter most in sectors like maritime transport, audiovisual services, and air transport services - which have been excluded from GATS disciplines. Progress will not be easy but bundling sectoral negotiations together (e.g. in transport) may help. It is also necessary to develop rules to ensure the non-discriminatory allocation of quotas and to maintain the desirable openness of the GATS provision covering mutual recognition agreements.

- If the GATS is to advance the process of services liberalization beyond levels undertaken independently, and lead to more balanced outcomes from the developing country point of view, then reciprocity must play a greater role in negotiations. This may be facilitated by devising negotiating formulae that establish credible links 
across sectors and across modes of delivery. And to overcome a possible hold-back problem, it is necessary to provide credible ex ante assurance of negotiating credit for unilateral liberalization.

Finally, three sets of issues have been neglected by this paper: how can the provisions of the GATS and the schedules of commitments be made clearer and more accessible?

What rules should be developed for safeguards, subsidies and government procurement? What form do preferential agreements in services take and how can GATS rules for such agreements be improved? Some work has been done in each of these areas but there is need for much more research. ${ }^{44}$

\section{References}

Adlung, Rudolf (2000), "Services Trade Liberalization from Developed and Developing Country Perspectives," in Sauvé, Pierre and Stern, Robert M. (eds.), 112-131.

Deardoff, Alan (1994), "Market Access," in the New World Trading System: Readings, OECD, Paris.

Feketekuty, Geza (2000), "Assessing and Improving the Architecture of GATS", in Sauvé, Pierre and Stern, Robert M. (eds.), 85-111.

Fink, Carsten, Mattoo, Aaditya and Neagu, Cristina (2000), Trade in International Maritime Services: How Much Does Policy Matter?, World Bank, mimeo.

Hummels, David (1999), “Have International Transportation Costs Declined?", manuscript (University of Chicago).

Hoekman, Bernard (1996), Assessing the General Agreement on Trade in Services," in The Uruguay Round and the Developing Countries, W. Martin and L. A. Winters (eds.), Cambridge: Cambridge University Press.

Hoekman, Bernard M. and Messerlin, Patrick A. (2000), "Liberalizing Trade in Services: Reciprocal Negotiations and Regulatory Reform", in Sauvé, Pierre and Stern, Robert M. (eds.), 487-508.

Hindley, Brian (1988), Service Sector protection: Consideration for Developing Countries, World Bank Economic review, 2, 205-24.

Hindley, Brian and Smith, Alasdair (1984), Comparative Advantage and Trade in Services, World Economy, 7, 369-90.

\footnotetext{
${ }^{44}$ See Sauve and Stern (2000).
} 
Nicolaïdis, Kalypso; Trachtman, Joel P. (2000), "From Policed Regulation to Managed Recognition in GATS", in Sauvé, Pierre and Stern, Robert M. (eds.), 241-282;

Laffont, Jean Jacques (1998), "Competition, Information and Development", Annual Bank Conference on Development Economics, The World Bank, Washington, D.C., April 20 and 21, 1-40;

Mattoo, Aaditya (2000) "Developing Countries and the New Round of GATS Negotiations: Towards a Pro-active Role," World Economy, 23, 471-89.

Mattoo, Aaditya, and Olarreaga, Marcelo (2000) "Reciprocity Across Modes of Supply: A Negotiating Formula," World Bank Policy Research Paper, forthcoming.

Mattoo, Aaditya, and Olarreaga, Marcelo (2000) "Should Credit be Given For Unilateral Liberalization in Multilateral Negotiations?," World Bank Policy Research Paper, forthcoming.

Mattoo, Aaditya (2000), MFN and the GATS, in Cottier, Thomas and Mavroidis, Petros (eds.), Most-Favoured Nation Treatment: Past and Present, Michigan University Press, Michigan.

Mattoo, Aaditya, and Subramanian, Arvind, 1998, "Regulatory Autonomy and Multilateral Disciplines, ” Journal of International Economic Law, 1, 303-322.

Nicolaidis, Kalypso and Joel P. Trachtman, 1999, "From Policed Regulation to Managed Recognition: Mapping the Boundary in GATS", in Sauvé, Pierre and Stern, Robert M. (eds.), 241-82.

Sapir, A. (1998), GATS 1994-2000, Journal of World Trade, 33, 51-66.

Sauvé, Pierre and Stern, Robert M. (2000), GATS 2000: New Directions in Services Trade Liberalization, Center for Business and Government (Harvard University); Brookings Institution Press (Washington D.C.).

Snape, Richard (1994), Services and the Uruguay Round, in the New World Trading System: Readings, OECD, Paris.

Stephenson, Sherry (2000), GATS and Regional Integration, in Sauvé, Pierre and Stern, Robert M. (eds.), 509-42;

Thompson, Rachel (2000), "Formula Approaches to Improving GATS Commitments", in Sauvé, Pierre Stern, Robert M. (2000), 473-486;

Tuthill, Lee, 1997, “The GATS and New Rules for Regulators," Telecommunications Policy, November. 
UNCTAD and World Bank (1994), "Liberalizing International Transactions in Services, A Handbook", United Nations, New York and Geneva. 
Table 1: East Asia: Foreign equity participation, degree of competition and nature of precommitment in fixed telecom networks

\begin{tabular}{|c|c|c|c|}
\hline Country & Limitations on FDI & Degree of Competition in fixed networks & Precommitment \\
\hline Hong Kong & None & $\begin{array}{l}\text { Oligopoly of } 5 \text { in domestic, monopoly in } \\
\text { international }\end{array}$ & $\begin{array}{l}\text { Will consider issuing more than the existing } \\
\text { four licences for local fixed network services } \\
\text { in June } 1998 .\end{array}$ \\
\hline Indonesia & GATS: 35 per cent & $\begin{array}{l}\text { Regional monopolies with scope for joint } \\
\text { operating schemes }\end{array}$ & $\begin{array}{l}\text { Policy review upon the expiry of the exclusive } \\
\text { rights: exclusivity expires in } 2011 \text { for local } \\
\text { service, in } 2006 \text { for long distance services, } \\
\text { and in } 2005 \text { for international service. }\end{array}$ \\
\hline Japan & $20 \%$ in NTT and KDD & Full competition & \\
\hline Korea & $\begin{array}{l}\text { Variable: } \\
\text { Facilities-based: } 33 \% \\
\text { Korea Telecom: } 20 \% \\
\text { Resale-based: } 0 \%\end{array}$ & $\begin{array}{l}\text { Full competition, phased in over several } \\
\text { years }\end{array}$ & $\begin{array}{l}\text { Will increase foreign equity limits: } \\
\text { Facilities-based: } 49 \% \text { in 2001) } \\
\text { Korea Telecom: } 33 \% \text { in 2001) } \\
\text { Resale-based: } 49 \% \text { in } 1999,100 \% \text { in } 2001\end{array}$ \\
\hline Malaysia & GATS: $30 \%$ & $\begin{array}{l}\text { Increasing competition; discretionary } \\
\text { licensing }\end{array}$ & \\
\hline Philippines & GATS: $40 \%$ & Full competition; discretionary licensing & \\
\hline Singapore & $\begin{array}{l}\text { GATS: } 73.99 \% \text { (direct: } 49 \% \text {, indirect: } \\
24.99 \% \text { ) }\end{array}$ & Monopoly. & Oligopoly of 3 or more after April 2000 \\
\hline Thailand & Limited, in BTO arrangements & Monopoly, with some BTO arrangements & $\begin{array}{l}\text { Will introduce revised commitments in } 2006 \\
\text { when new law comes into force. }\end{array}$ \\
\hline
\end{tabular}


The abbreviations used in tables 2 and 3 are the following:

$\begin{array}{llll}\text { B: } & \text { branches } & \text { U: } & \text { unbound (no commitment) } \\ \text { S: } & \text { subsidiaries } & \text { R: } & \text { reciprocity condition or MFN exemption } \\ \text { h: } & \text { restrictions in horizontal commitments } & \text { DL: } & \text { discretionary licensing or economic needs test } \\ \text { I: } & \text { local incorporation required } & \text { (D)LSO: (discretionary) limits on single ownership } \\ \text { None: } & \text { commitment to impose no restrictions } & \text { G: } & \text { grandfathering provisions }\end{array}$

Table 2: Market Access Commitments in Insurance (Direct: Life and Non-Life): East Asia

\begin{tabular}{|c|c|c|c|c|c|c|}
\hline \multirow[t]{2}{*}{ Member } & \multirow{2}{*}{$\begin{array}{l}\text { Ltms on } \\
\text { Cross } \\
\text { border }\end{array}$} & \multirow{2}{*}{$\begin{array}{l}\text { Ltns on } \\
\text { Consn } \\
\text { abroad }\end{array}$} & \multicolumn{4}{|c|}{ Limitations on commercial presence } \\
\hline & & & Legal form & $\begin{array}{l}\text { No. of } \\
\text { suppliers }\end{array}$ & Equity & Other \\
\hline Brunei Dar. & U & $\begin{array}{l}\text { none excl. } \\
\text { statutory ins. }\end{array}$ & $\begin{array}{l}\text { local } \\
\text { registration }\end{array}$ & $\mathrm{U}(\mathrm{h})$ & $U(h)$ & \\
\hline Hong Kong & $\mathrm{U}$ & $\begin{array}{l}\text { none excl } \\
\text { statutory ins }\end{array}$ & $\begin{array}{l}\text { S, B or } \\
\text { association of } \\
\text { underwriters }\end{array}$ & & & \\
\hline Indonesia & $\mathrm{U}$ & DL & & & $100 \%$ of listed cos. (G) & \\
\hline \multirow[t]{2}{*}{ Japan } & \multicolumn{2}{|l|}{ life: $U$} & & & & \\
\hline & \multicolumn{2}{|c|}{$\begin{array}{l}\text { non-life: for limited class; } \\
\text { only with mode } 3 \text { for some } \\
\text { services }\end{array}$} & & & & \\
\hline Korea & $\begin{array}{l}U \text { except } \\
\text { marine cargo } \\
\text { and aviation } \\
\text { ins. }\end{array}$ & $\mathbf{U}$ & $\begin{array}{l}S, B, \text { joint } \\
\text { ventures (but } \\
\text { not with } \mathrm{K} \\
\text { lics) }\end{array}$ & & $\begin{array}{l}\text { restrictions on } \\
\text { acquisition of existing } \\
\text { firms; foreign portfolio } \\
\text { invt only for listed } \\
\text { stocks, } \leq 23 \% \text { (h) } \\
\text { LSO }\end{array}$ & \\
\hline \multirow[t]{2}{*}{ Malaysia } & life: $U$ & life: $U$ & \multirow[t]{2}{*}{ I } & \multirow[t]{2}{*}{ new: $\mathrm{U}$} & \multirow[t]{2}{*}{$\begin{array}{l}\text { on incorpn of existing } \\
\text { branches and for } \\
\text { original owners: } 51 \% \text {; } \\
\text { new particpn in existing } \\
30 \% \text { (DLSO) }\end{array}$} & \multirow[t]{2}{*}{$\begin{array}{l}\text { No branches } \\
\text { for foreign> } \\
50 \%(G)\end{array}$} \\
\hline & non-life: $\mathrm{DL}$ & non-life: DL & & & & \\
\hline Philippines & $\begin{array}{l}\text { U except for } \\
\text { marine hull } \\
\text { and marine } \\
\text { cargo }\end{array}$ & $\mathbf{U}$ & & DL & $\begin{array}{l}\text { acquisition or new: } \\
51 \% \\
\text { (G) }\end{array}$ & \\
\hline Singapore & $\mathrm{U}$ & $\begin{array}{l}\text { none, excl } \\
\text { statutory ins }\end{array}$ & & New:U & $\begin{array}{l}\text { existing: } 49 \% \text { provided } \\
\text { no foreign party is } \\
\text { largest shareholder }\end{array}$ & \\
\hline \multirow[t]{2}{*}{ Thailand } & $\begin{array}{l}\text { U except for } \\
\text { internl } \\
\text { marine, } \\
\text { aviation and } \\
\text { transit }\end{array}$ & none & & \multirow[t]{2}{*}{ DL } & \multirow[t]{2}{*}{$25 \%$} & \\
\hline & $\begin{array}{l}\text { non-life for } \\
\text { ltd class }\end{array}$ & $\begin{array}{l}\text { non-life:none } \\
\text { for ltd. class }\end{array}$ & & & & \\
\hline
\end{tabular}


Table 3: Market Access Commitments in Banking (Acceptance of Deposits and Lending): East Asia

\begin{tabular}{|c|c|c|c|c|c|c|c|c|}
\hline \multirow[t]{2}{*}{ Member } & \multirow{2}{*}{$\begin{array}{l}\text { Ltns on } \\
\text { Cross } \\
\text { border }\end{array}$} & \multirow{2}{*}{$\begin{array}{l}\text { Ltns on } \\
\text { Consn } \\
\text { abroad }\end{array}$} & \multicolumn{6}{|c|}{ Limitations on commercial presence } \\
\hline & & & Legal form & $\begin{array}{l}\text { No. of } \\
\text { suppliers }\end{array}$ & Equity & $\begin{array}{l}\text { Number of } \\
\text { operns } \\
\text { (branches) }\end{array}$ & $\begin{array}{l}\text { Value of } \\
\text { Transns or } \\
\text { Assets }\end{array}$ & Other \\
\hline \multirow[t]{2}{*}{ Hong Kong } & \multirow[t]{2}{*}{$\mathbf{U}$} & \multirow[t]{2}{*}{ None } & $\begin{array}{l}\text { deposits: } \mathbf{S} \\
\text { or B }\end{array}$ & $\begin{array}{l}\text { DL for } \\
\text { acquistion } \\
\text { of locally } \\
\text { inc bank }\end{array}$ & & $\begin{array}{l}\text { For banks } \\
\text { inc. } \\
\text { overseas, } \\
\text { max } \\
\text { offices }=3 \\
\text { (G) }\end{array}$ & & $\begin{array}{l}\text { For } S, 10 \\
\text { years as } \\
\text { authorz } \\
\text { instn. }\end{array}$ \\
\hline & & & \multicolumn{6}{|c|}{ Lending: none } \\
\hline Indonesia & None & None & $\begin{array}{l}\text { New: I, } \\
\text { joint } \\
\text { venture } \\
\text { (G of old } \\
\text { B) }\end{array}$ & new:U & $\begin{array}{l}\text { acquisn of } \\
\text { existing: } \\
49 \% \\
\text { (G) }\end{array}$ & $\begin{array}{l}2 \mathrm{~B} / \text { aux. } \\
\text { office }\end{array}$ & & \\
\hline Japan & $\mathbf{U}$ & None & & & & & & \\
\hline Korea & $\mathrm{U}$ & $\mathrm{U}$ & & $\begin{array}{l}\text { only } \\
\text { branches of } \\
\text { top } 500 \\
\text { banks; } \\
\text { unclear on } \\
\mathrm{S}\end{array}$ & $\begin{array}{l}\text { restrns on } \\
\text { acquisn of } \\
\text { existing } \\
\text { firms; } \\
\text { foreign } \\
\text { portfolio } \\
\text { invt only } \\
\text { for listed } \\
\text { stocks, and } \\
\leq 23 \% \text { (h) } \\
\text { LSO }\end{array}$ & & $\begin{array}{l}\text { ceilings on } \\
\text { foreign } \\
\text { currency } \\
\text { loans }\end{array}$ & \\
\hline \multirow[t]{2}{*}{ Malaysia } & deposits:U & None & & new: $U$ & $\begin{array}{l}\text { existing: } \\
30 \% \\
\text { (G) } \\
\text { DLSO }\end{array}$ & $\begin{array}{l}U \text { for B } \\
\text { and ATMs } \\
\text { of comml } \\
\text { banks }\end{array}$ & & \\
\hline & \multicolumn{2}{|c|}{$\begin{array}{l}\text { Lending } \geq \text { RM } 25 \mathrm{~m} \text { only } \\
\text { with mode } 3\end{array}$} & & & & & & \\
\hline PNG (o) & none & none & \multicolumn{6}{|l|}{ none } \\
\hline $\begin{array}{l}\text { Philip- } \\
\text { pines }\end{array}$ & $\mathrm{U}$ & none & $\begin{array}{l}\text { Single } \\
\text { form of } \\
\text { presence }+ \\
\text { local } \\
\text { incorp: } \\
\text { DL }\end{array}$ & $\mathrm{DL}, \mathbf{R}$ & $\begin{array}{l}\text { acquisition } \\
\text { or new: } \\
51 \% \\
\text { (G) }\end{array}$ & $\begin{array}{l}10 \text { new } B \\
(1995- \\
2000) \\
\text { indvl } \\
\max =6\end{array}$ & $\begin{array}{l}30 \% \max \\
\text { foreign } \\
\text { share of } \\
\text { total assets }\end{array}$ & \\
\hline \multirow[t]{2}{*}{ Singapore } & \multirow[t]{2}{*}{$\mathrm{U}$} & \multirow[t]{2}{*}{ none } & & $\begin{array}{l}\text { deposits } \\
\text { new :U }\end{array}$ & $\begin{array}{l}\text { deposits: } \\
40 \% \\
\text { LSO }\end{array}$ & $\begin{array}{l}\text { deposits: } 1 \\
\text { office } \\
\text { (incl. } \\
\text { ATM) }\end{array}$ & & \\
\hline & & & & $\begin{array}{l}\text { lending: } \\
\text { none }\end{array}$ & $\begin{array}{l}\text { lending: } \\
\text { none }\end{array}$ & $\begin{array}{l}\text { lending:off } \\
\text { premise } \\
\text { ATM: U }\end{array}$ & $\begin{array}{l}\text { lending } \\
\text { local } \\
\text { currency to } \\
\text { non-res: } \\
\text { DL }\end{array}$ & \\
\hline Thailand & $\mathrm{U}$ & $\mathrm{U}$ & I or $\mathbf{B}$ & $\begin{array}{l}\text { S: U } \\
\text { B: DL }\end{array}$ & $\begin{array}{l}\text { acquisition } \\
\text { of existing: } \\
25 \% \text { (Itns. } \\
\text { on indvl. } \\
\text { ownership) } \\
\text { DL on } \\
>25 \%\end{array}$ & $\begin{array}{l}\text { existing } \\
\text { banks with } \\
\text { a B before } \\
1995: 2 \\
\text { addnl Bs } \\
\text { (G); new } \\
\text { Bs: DL }\end{array}$ & & \\
\hline
\end{tabular}


Table 4: Grandfather provisions in GATS Schedules on banking and insurance services: East Asia

\begin{tabular}{|c|c|}
\hline Country & Provision \\
\hline \multicolumn{2}{|c|}{ Foreign equity-related } \\
\hline Indonesia & $\begin{array}{l}\text { Banking and insurance: Share ownership of foreign services suppliers is bound at the prevailing laws } \\
\text { and regulations. The conditions of ownership and the percentage share of ownership as stipulated in the } \\
\text { respective shareholder agreement establishing the existing individual joint venture shall be respected. No } \\
\text { transfer of ownership shall take place without the consent of all parties in the joint venture concerned. }\end{array}$ \\
\hline Malaysia & $\begin{array}{l}\text { Banking: Entry is limited to equity participation by foreign banks in Malaysian-owned or controlled } \\
\text { commercial and merchant banks with aggregate foreign shareholding not to exceed } 30 \text { per cent, but the } \\
\text { thirteen wholly-foreign owned commercial banks are permitted to remain wholly-owned by their existing } \\
\text { shareholders. } \\
\text { Insurance: New entry is limited to equity participation by foreign insurance companies in locally } \\
\text { incorporated insurance companies with aggregate foreign shareholding not to exceed } 30 \% \text {. Foreign } \\
\text { shareholding not exceeding } 51 \% \text { is also permitted when (i) existing branches of foreign insurance } \\
\text { companies are locally incorporated, which they are required to be by } 30 \text { June } 1998 \text {, and (ii) for the } \\
\text { existing foreign shareholders of locally incorporated insurance companies which were the original } \\
\text { owners of these companies. }\end{array}$ \\
\hline $\begin{array}{l}\text { Philip- } \\
\text { pines }\end{array}$ & $\begin{array}{l}\text { Insurance and banking: New investments of up to } 51 \% \text { of the voting stock, but existing investments of } \\
\text { foreign banks will be maintained at their existing levels. }\end{array}$ \\
\hline \multicolumn{2}{|c|}{ Legal form-related } \\
\hline $\begin{array}{l}\text { Hong } \\
\text { Kong }\end{array}$ & $\begin{array}{l}\text { Banking: The condition that branches of foreign banks are allowed to maintain offices in one main } \\
\text { building and no more than two additional offices in separate buildings, does not apply to banks } \\
\text { incorporated outside HKSAR licensed before May } 1978 \text { in respect of fully licensed banks and before } \\
\text { April } 1990 \text { in respect of restricted licence banks. }\end{array}$ \\
\hline Indonesia & $\begin{array}{l}\text { Banking: Existing branches of foreign banks are exempted from the requirement imposed on new } \\
\text { entrants to be in the form of locally incorporated joint venture banks. }\end{array}$ \\
\hline Malaysia & $\begin{array}{l}\text { Insurance: Branching is only permitted for direct insurance companies with aggregate foreign } \\
\text { shareholding of less than } 50 \text { per cent but companies are permitted to maintain their existing network of } \\
\text { branches. (See also foreign equity-related provision above.) }\end{array}$ \\
\hline Thailand & $\begin{array}{l}\text { Banking: While the establishment of new branches is subject to discretionary licensing, existing foreign } \\
\text { banks which already had the first branch office in Thailand prior to July } 1995 \text { will each be permitted to } \\
\text { open no more than two additional branches. }\end{array}$ \\
\hline \multicolumn{2}{|l|}{ General } \\
\hline $\begin{array}{l}\text { Philip- } \\
\text { pines }\end{array}$ & $\begin{array}{l}\text { Insurance: Limitations in market access listed in the specific insurance sub-sectors do not apply to } \\
\text { existing wholly or majority foreign-owned authorized insurance/reinsurance companies as of the entry } \\
\text { into force of the WTO Financial Services agreement. }\end{array}$ \\
\hline
\end{tabular}


Policy Research Working Paper Series

\section{Title}

WPS2577 Developing Rainfall-Based Index Insurance in Morocco

WPS2578 How Accession to the European Union Has Affected External Trade and Foreign Direct Investment in Central European Economies

WPS2579 Public Health and Education Spending in Ghana in 1992-98: Issues of Equity and Efficiency

WPS2580 On "Indirect" Trade-Related Research and Development Spillovers

WPS2581 Securities Clearance and Settlement Systems: A Guide to Best Practices

WPS2582 Development Financing during a Crisis: Securitization of Future Receivables

WPS2583 How the Location of Roads and Protected Areas Affects Deforestation in North Thailand

WPS2584 Structural Adjustment and Forest Resources: The Impact of World Bank Operations

WPS2585 Law, Politics, and Finance

WPS2586 On the Urbanization of Poverty

WPS2587 Growth is Good for the Poor

WPS2588 The Regulation and Supervision of Banks around the World: A New Database

\section{Author}

Jerry Skees

Stephanie Gober

Panos Varangis

Rodney Lester

Vijay Kalavakonda

Bartlomiej Kaminski

April 2001

Sudharshan Canagarajah

Xiao Ye

Olivier Lumenga-Neso

Marcelo Olarreaga

Maurice Schiff

Mario Guadamillas

Robert Keppler

Suhas Ketkar

Dilip Ratha

Maureen Cropper

Jyotsna Puri

Charles Griffiths

Kiran D. Pandey

David Wheeler

Thorsten Beck

Asli Demirgüç-Kunt

Ross Levine

Martin Ravallion

David Dollar

Aart Kraay

James R. Barth

Gerard Caprio Jr.

Ross Levine
Date

April 2001

April 2001

Contact for paper

P. Kokila 33716

L. Tabada 36896

M. Clarke

31752

April 2001

L. Tabada 36896

April 2001

H. Issa

30154

April 2001

S. Crow

30763

April 2001

V. Soukhanov 35721

April 2001

Y. D"Souza 31449

April 2001

A. Yaptenco 31823

April 2001

C. Cunanan 32301

April 2001

E. Khine 37471

April 2001

A. Yaptenco 38526 
Policy Research Working Paper Series

\begin{tabular}{|c|c|c|c|c|}
\hline & Title & Author & Date & $\begin{array}{l}\text { Contact } \\
\text { for paper }\end{array}$ \\
\hline WPS2589 & $\begin{array}{l}\text { Implementing the Market Approach } \\
\text { to Enterprise Support: An Evaluation } \\
\text { of Ten Matching Grant Schemes }\end{array}$ & David A. Phillips & April 2001 & $\begin{array}{l}\text { S. Torres } \\
39012\end{array}$ \\
\hline WPS2590 & $\begin{array}{l}\text { Household Welfare and Poverty } \\
\text { Dynamics in Burkina Faso: Empirical } \\
\text { Evidence from Household Surveys }\end{array}$ & $\begin{array}{l}\text { Hippolyte Fofack } \\
\text { Célestin Monga } \\
\text { Hasan Tuluy }\end{array}$ & April 2001 & $\begin{array}{l}\text { N. Nouviale } \\
34514\end{array}$ \\
\hline WPS2591 & $\begin{array}{l}\text { Hirschmanian Themes of Social } \\
\text { Learning and Change }\end{array}$ & David Ellerman & April 2001 & $\begin{array}{l}\text { B. Mekuria } \\
82756\end{array}$ \\
\hline WPS2592 & $\begin{array}{l}\text { Management of Oil Windfalls in } \\
\text { Mexico: Historical Experience and } \\
\text { Policy Options for the Future }\end{array}$ & $\begin{array}{l}\text { Stephen Everhart } \\
\text { Robert Duval-Hernandez }\end{array}$ & April 2001 & $\begin{array}{l}\text { M. Kam-Cheong } \\
39618\end{array}$ \\
\hline WPS2593 & $\begin{array}{l}\text { Changing Trade Patterns after } \\
\text { Conflict Resolution in the South } \\
\text { Caucasus }\end{array}$ & Evgeny Polyakov & April 2001 & $\begin{array}{l}\text { Z. Nekaien-Nowrouz } \\
39057\end{array}$ \\
\hline WPS2594 & $\begin{array}{l}\text { Committing to Civil Service Reform: } \\
\text { The Performance of Pre-Shipment } \\
\text { Inspection under Different Institutional } \\
\text { Regimes }\end{array}$ & Noel Johnson & April 2001 & $\begin{array}{l}\text { L. Barbone } \\
32556\end{array}$ \\
\hline WPS2595 & $\begin{array}{l}\text { Unrestricted Market Access for } \\
\text { Sub-Saharan Africa: How Much Is it } \\
\text { Worth and Who Pays? }\end{array}$ & $\begin{array}{l}\text { Elena lanchovichina } \\
\text { Aaditya Mattoo } \\
\text { Marcelo Olarreaga }\end{array}$ & April 2001 & $\begin{array}{l}\text { L. Tabada } \\
36896\end{array}$ \\
\hline
\end{tabular}

